\title{
CHANGES AND DIFFERENCES IN POLES' HIERARCHY OF VALUES - ON BASIS OF THE EUROPEAN SOCIAL SURVEY
}

Krzysztof Błoński, Ph.D.

University of Szczecin

Faculty of Economics and Management

Marketing Department

Mickiewicza 64, 71-101 Szczecin, Poland

e-mail:kblonski@wneiz.pl

Received 15 March 2015, Accepted 3 December 2015

\begin{abstract}
The purpose of this paper is to present the changes that have place with regard to Poles' value system over the last 12 years, as well as to demonstrate differences based on sex, level of education and household income level. The analysis was based on the results of the European Social Survey (ESS). The research results indicate that the hierarchy of values cherished by Poles does not undergo significant changes. The most important values are security, universalism and benevolence. The least significant values include hedonism, stimulation and power. There are no identifiable differences in the hierarchies of values of women and men. However, there are noticeable differences depending on the level of education, household income level and age of surveyed respondents.
\end{abstract}

Keywords: human values, hierarchy of values, existing data

JEL classification: A14, J17, Z13 


\section{Introduction}

Values create a framework for individual's thoughts, stances and behaviours. They form a consistent system that makes it possible for a person not only to survive, but also to achieve happiness in private life as well as professional success and satisfaction. The adopted value system influences one's everyday life, the choice of future directions to pursue as well as one's attitude towards other people (Lachowski, 2012, pp. 19-21).

A system of values is also a significant part of the culture an individual lives in and it forms the reality, towards which one must take a stance. Values stimulate and shape an individual's awareness, they motivate him/her to take up activity, influence the intended purposes of actions and in addition integrate people and unify societies, stimulate, orientate and sustain development (Dyczewski, 2001, p. 39).

The term "value"1 is used in philosophy, sociology, psychology, cultural anthropology, economics and management theory. ${ }^{2}$ That is the reason why its definitions differ and why it is presented from different perspectives. As a result numerous different theories of values and various research methods are used. Due to the existing diversity of hierarchies of values, while looking for similarities between them, we have to realize, what the possible levels of analysis are. We can name at least five following levels of analyzing values and hierarchies of values. There are: 1. individual level, 2. group level (applicable to e.g. family, students taking a class, group of friends), 3. community level (applicable to a local or regional community), 4. culture level (applicable to a nation, ethnic group) and 5. transcultural level (basic human level). The aforementioned levels correspond with the following hierarchies: 1. individual, 2. group, 3. typical for a community, 4. model (typical for a culture) and 5. universal (Brzozowski, 2007, p. 11). According to J. Szymczyk research into values can be conducted from two perspectives. The first one is the "macrostructural" perspective ("orientation towards the society") that comprises viewing different forms and categories of social life through the lens of axiology. It is not excluding the possibility of conducting research from the perspective of the individual ("orientation towards the individual") i.e. trying to identify certain values in the individuals under study, or the sets of values or at least some kind of "axiological atmosphere" that the subjects subscribe to. In connection with the aforementioned perspectives, the author divides values into: sociocentric (viewing reality through the lens of social systems and groups) and

\footnotetext{
1 The term value is often substituted with numerous similar terms such as: judgement, norm, aspirations, goals, objectives, interests. Jałowiecki (1976), p. 206.

2 An overview of issues connected with the ways of defining values in philosophy, economics, cultural anthropology and other social sciences can be found in the anthology Wartość dla klienta... (2011).
} 
allocentric (perceiving the world from the standpoint of another human being as an autonomous unit) (Szymczyk, 2010, p. 4).

Among examples of cyclical research concerned with the values of Polish society one can name the World Value Survey (WVS), the European Value Survey (EVS), the European Social Survey (ESS) or surveys of public opinion research agencies (e.g. CBOS) (Wartości $i$ normy, 2013). Results of research into the Poles' system of values can be found among others in the following works Wartości i zmiany (2012), P. Brzozowski (2007), whereas deliberations on the theme are included in the works by e.g. S. Nowak (2007) or J. Szymczyk (2010) or M. Ziółkowski (2006).

The purpose of this paper is to present the changes in the Poles' values system that have been taking place during the last 12 years, as well as to show the differences in terms of sex, age, education level and household income. The results of research conducted within the European Social Survey (ESS) for the years $2002-2013^{3}$ were the basis for the analyses.

\section{Research and analysis methodology}

The analysis of changes in the hierarchy of values has been based on the existing primary data of a subjective kind. The data originates from the results of international comparative research (European Social Survey, ESS). The objective of the ESS research is to observe the social changes happening in Europe, i.e. changes in attitudes towards key issues, changes in systems of values and behaviours. Some of the questions asked within individual rounds of the survey are the same and some of them (the rotating modules) are subject to change. This analysis uses the answers to questions asked within the core module regarding values held. The measurement of values is based on the theory of S. Schwartz, which proposes the existence of 10 values that can be arranged according to their contents in such a way that categories of values create a comprehensive system linked by relations of content similarity and dissimilarity as well as compatibility and conflict of motives that the contents relate to (Brzozowski, 2007, p. 9). The measurement of values held by the subjects was based on a specially constructed scale comprising of 21 statements. The answers to the questions were scaled on a 6-level ordering scale. ${ }^{4}$ For the needs of further analyses the assumption of quasi-quantitative nature of the ordering scale has been adopted. The reliability of the scale has been estimated using the

\footnotetext{
3 When the article was submitted to the editorial board (February 2015), the results of 2014 survey were not yet available. The results of the seventh round of the survey were published in October 2015.

4 Where 1 stood for "very much like me", whereas 6 stood for "completely not like me".
} 
Cronbach alpha. The results calculated for the individual rounds of the survey are above 0.8 , which means that the scales are characterized by a high level of reliability.

In the next stage the answers were divided into groups corresponding with the basic values defined by S. Schwartz (1992, 2005). The characteristics of individual values were presented in Table 1. Based on the received answers the indexes have been determined for individual values. Each of the indexes is the difference between the mean of aspects forming a given value and the mean of all the answers.

Table 1. The characteristics of human values according to Schwartz

\begin{tabular}{|l|l|l|}
\hline No. & \multicolumn{1}{|c|}{ Name } & \multicolumn{1}{c|}{ Characteristics } \\
\hline 1 & Self-Direction & Independent thought and action: choosing, creating, exploring \\
\hline 2 & Stimulation & Excitement, novelty and challenge in life \\
\hline 3 & Hedonism & Pleasure and sensuous gratification for oneself \\
\hline 4 & Achievement & Personal success through demonstrating competence according to social standards \\
\hline 5 & Power & Social status and prestige, control or dominance over people and resources \\
\hline 6 & Security & Safety, harmony and stability of society, of relationships, and of self \\
\hline 7 & Conformity & $\begin{array}{l}\text { Restraint of actions, inclinations, and impulses likely to upset or harm others and violate } \\
\text { social expectations or norms }\end{array}$ \\
\hline 8 & Tradition & $\begin{array}{l}\text { Respect, commitment, and acceptance of the customs and ideas that traditional culture } \\
\text { or religion provide the self }\end{array}$ \\
\hline 9 & Benevolence & $\begin{array}{l}\text { Preserving and enhancing the welfare of those with whom one is in frequent personal } \\
\text { contact }\end{array}$ \\
\hline 10 & Universalism & $\begin{array}{l}\text { Understanding, appreciation, tolerance, and protection for the welfare of all people } \\
\text { and for nature }\end{array}$ \\
\hline
\end{tabular}

Source: own work based on data available on the website http://www.europeansocialsurvey.org (access date: 15.07.2014).

The categories of values described above form a circular structure ordered according to the content relation "similarity - dissimilarity" of values and according to "compatibility conflict of interest". The first proposition for ordering is based on the principle of similarity, which enables us to identify group values (benevolence, tradition, conformity), individual values (self-direction, stimulation, hedonism, achievement, power) and common (mixed) values i.e. universalism and security. The second proposition of ordering is also situated within a twodimensional space and assumes that the two extreme poles corresponding to the dimensions should be marked as: self-transcendence - self-enhancement and openness to change conservation. The details regarding the placement of individual values are presented in Figures 1 and 2. 


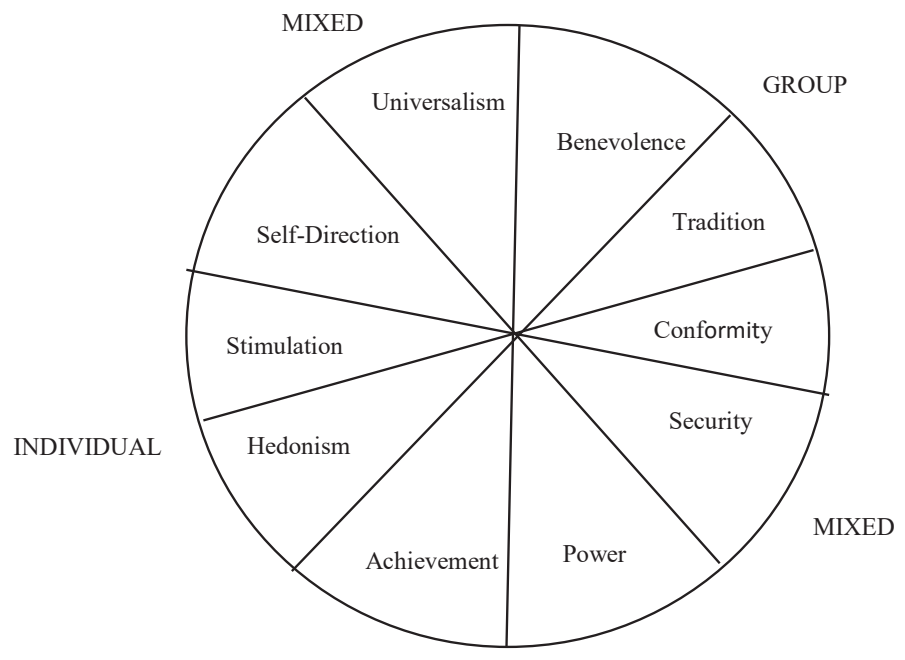

Figure 1. Ordering the categories of values according to the principle of interest Source: Brzozowski (2007), p. 61.

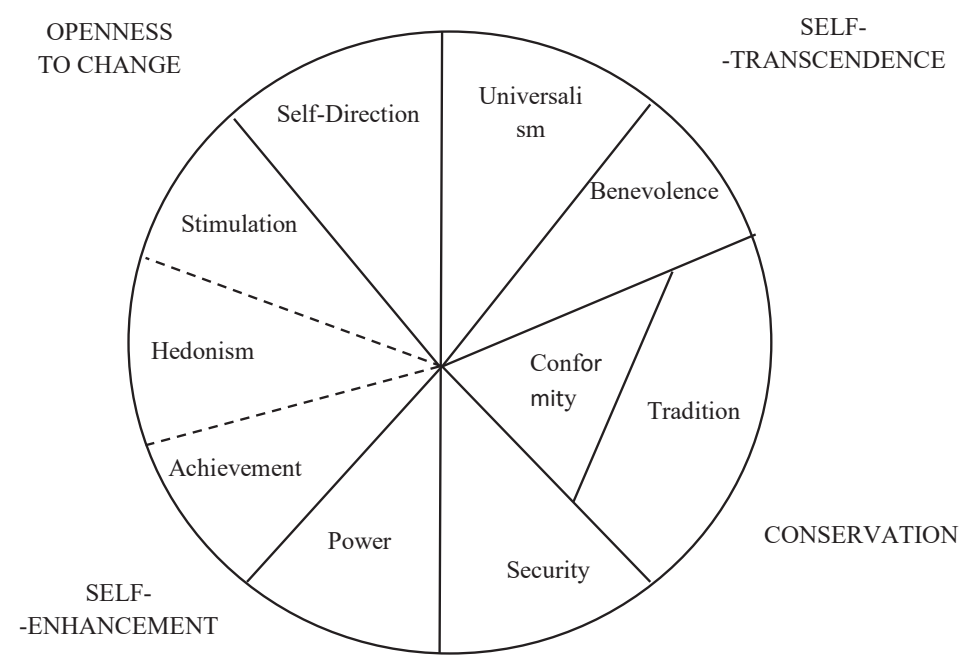

Figure 2. Theoretical model of relations between the ten kinds of values based on the principle of compatibility and conflict

Source: Schwartz (2003). 


\section{Changes in Poles' hierarchy of values}

The comparison of hierarchies of values originating from six rounds of the research has been conducted using the frequency of declarations of a particularly high degree of identification with people who hold the individual values ( 1 or 2 on a scale from 1 to 6$).{ }^{5}$ As a result of analyzing the data presented in Table 3 we can see the following ranking:

1. Within the hierarchy of individual's values the most fundamental domain contains the values associated with universalism, benevolence and security. On average, between $70 \%$ and $80 \%$ of surveyed population identified with them on a level of 1 or 2 , depending on the round of the research. Most frequently the subjects identified themselves with the following aspects comprising the values: the conviction that all people should be treated equally (ca. $80 \%$ of answers in each round of the survey); loyalty towards friends (between $78 \%$ and $85 \%$ of answers); the conviction of a duty to care for the environment (between $73 \%$ and $81 \%$ of answers). The issues of understanding and caring for other people are an exception in that group. In these cases the percentage of answers is lower than in the aforementioned examples and falls within the range between $55 \%$ and $69 \%$. That is why it is difficult to draw a clear line between the first and the second group of values.

2. The second place belongs to the domain of values connected with tradition, conformity ${ }^{6}$ and self-direction. These values were indicated as especially important by $45 \%$ to $69 \%$ of participants. In particular, they pointed at: the duty to behave properly (over $60 \%$ of answers in each round of the survey) and the importance of being humble and modest (between $47 \%$ and $53 \%$ of answers). It is worth noting that there is a high percentage of answers asserting the importance of tradition and making one's own decisions regarding one's own matters, which brings them closer to the first group.

3. The next place is occupied by the group of values related to stimulation, hedonism, achievement and power. It needs to be emphasized that the individual aspects comprising the values have a different meaning in the opinion of participants and as a result the percentage of highest responses varies between $20 \%$ and $45 \%$. Within this group the participants identified themselves most frequently with the importance of getting respect from others (between $43 \%$ and $52 \%$ of answers) as well as with trying

\footnotetext{
5 The assessment of degree of identification was based on a 6-point scale, where 1 stood for "very much like me" and 6 for "completely not like me."

${ }^{6}$ Conformity and benevolence values both promote cooperative and supportive social relations. However, benevolence values provide an internalized motivational base for such behaviour. In contrast, conformity values promote cooperation in order to avoid negative outcomes for self.
} 
out new things in life (over $45 \%$ of answers in each survey). In contrast, the lowest degree of identification is declared in case of the importance of being rich and seeking exciting adventures.

Table 2. Ranking of aspects comprising individual values according to the frequency of responses with the level of identification " 1 " and " 2 " (on a scale of " 1 to 6 " in \%)

\begin{tabular}{|c|c|c|c|c|c|c|c|c|c|c|c|c|c|}
\hline \multirow[b]{2}{*}{ Value } & \multirow[b]{2}{*}{$\begin{array}{c}\text { Aspects } \\
\text { comprising } \\
\text { a given value }\end{array}$} & \multicolumn{2}{|c|}{2002} & \multicolumn{2}{|l|}{2004} & \multicolumn{2}{|l|}{2006} & \multicolumn{2}{|l|}{2008} & \multicolumn{2}{|l|}{2010} & \multicolumn{2}{|l|}{2012} \\
\hline & & $\begin{array}{l}\text { Percent- } \\
\text { age of } \\
\text { answers }\end{array}$ & 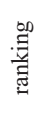 & $\begin{array}{l}\text { Percent- } \\
\text { age of } \\
\text { answers }\end{array}$ & 兽 & $\begin{array}{l}\text { Percent- } \\
\text { age of } \\
\text { answers }\end{array}$ & 音 & $\begin{array}{l}\text { Percent- } \\
\text { age of } \\
\text { answers }\end{array}$ & 兽 & $\begin{array}{l}\text { Percent- } \\
\text { age of } \\
\text { answers }\end{array}$ & 咅 & $\begin{array}{l}\text { Percent- } \\
\text { age of } \\
\text { answers }\end{array}$ & 品 \\
\hline 1 & 2 & 3 & 4 & 5 & 6 & 7 & 8 & 9 & 10 & 11 & 12 & 13 & 14 \\
\hline \multirow[t]{2}{*}{ Conformity } & $\begin{array}{l}\text { important to } \\
\text { do what is } \\
\text { told and fol- } \\
\text { low rules }\end{array}$ & 67.8 & 8 & 62.9 & 10 & 64.2 & 9 & 60.9 & 11 & 59.4 & 11 & 64.2 & 11 \\
\hline & $\begin{array}{l}\text { important } \\
\text { to behave } \\
\text { property }\end{array}$ & 67.7 & 9 & 68.8 & 8 & 68.5 & 8 & 61.9 & 10 & 63.8 & 9 & 69.0 & 9 \\
\hline \multirow[t]{2}{*}{ Tradition } & $\begin{array}{l}\text { important to } \\
\text { be humble } \\
\text { and modest, } \\
\text { not draw } \\
\text { attention }\end{array}$ & 51.6 & 12 & 51.4 & 12 & 50.9 & 12 & 47.7 & 13 & 48.6 & 14 & 53.8 & 12 \\
\hline & $\begin{array}{l}\text { important } \\
\text { to follow } \\
\text { traditions and } \\
\text { customs }\end{array}$ & 73.4 & 6 & 74.2 & 6 & 72.8 & 7 & 69.4 & 6 & 70.8 & 6 & 74.8 & 7 \\
\hline \multirow{2}{*}{$\begin{array}{l}\text { Benevo- } \\
\text { lence }\end{array}$} & $\begin{array}{l}\text { important to } \\
\text { help people } \\
\text { and care for } \\
\text { others well- } \\
\text { being }\end{array}$ & 60.5 & 10 & 64.5 & 9 & 61.1 & 11 & 63.3 & 8 & 68.0 & 8 & 69.4 & 8 \\
\hline & $\begin{array}{l}\text { important to } \\
\text { be loyal to } \\
\text { friends and } \\
\text { devote to } \\
\text { people close }\end{array}$ & 79.1 & 4 & 84.1 & 1 & 81.1 & 2 & 78.3 & 1 & 82.0 & 1 & 84.6 & 2 \\
\hline \multirow{3}{*}{$\begin{array}{l}\text { Universal- } \\
\text { ism }\end{array}$} & $\begin{array}{l}\text { important } \\
\text { that people } \\
\text { are treated } \\
\text { equally and } \\
\text { have equal } \\
\text { opportunities }\end{array}$ & 85.0 & 1 & 81.3 & 2 & 82.8 & 1 & 77.0 & 2 & 80.1 & 2 & 84.9 & 1 \\
\hline & $\begin{array}{l}\text { important to } \\
\text { understand } \\
\text { different } \\
\text { people }\end{array}$ & 55.0 & 11 & 53.4 & 11 & 64.1 & 10 & 62.3 & 9 & 63.2 & 10 & 68.6 & 10 \\
\hline & $\begin{array}{l}\text { important } \\
\text { to care for } \\
\text { nature and } \\
\text { environment }\end{array}$ & 75.1 & 5 & 78.1 & 4 & 76.1 & 4 & 73.4 & 4 & 74.7 & 5 & 81.1 & 3 \\
\hline
\end{tabular}




\begin{tabular}{|c|c|c|c|c|c|c|c|c|c|c|c|c|c|}
\hline 1 & 2 & 3 & 4 & 5 & 6 & 7 & 8 & 9 & 10 & 11 & 12 & 13 & 14 \\
\hline \multirow{2}{*}{$\begin{array}{l}\text { Self-direc- } \\
\text { tion }\end{array}$} & $\begin{array}{l}\text { important to } \\
\text { think new } \\
\text { ideas and be } \\
\text { creative }\end{array}$ & 46.7 & 14 & 45.7 & 14 & 45.8 & 15 & 48.7 & 12 & 49.4 & 13 & 48.6 & 14 \\
\hline & $\begin{array}{l}\text { important to } \\
\text { make own } \\
\text { decisions and } \\
\text { be free }\end{array}$ & 73.0 & 7 & 72.3 & 7 & 74.6 & 5 & 68.9 & 7 & 70.6 & 7 & 76.9 & 6 \\
\hline \multirow[b]{2}{*}{ Stimulation } & $\begin{array}{l}\text { important } \\
\text { to try new } \\
\text { and different } \\
\text { things in life }\end{array}$ & 47.6 & 13 & 45.1 & 15 & 47.6 & 14 & 45.4 & 15 & 45.1 & 15 & 46.1 & 16 \\
\hline & $\begin{array}{l}\text { important } \\
\text { to seek } \\
\text { adventures } \\
\text { and have an } \\
\text { exciting life }\end{array}$ & 21.0 & 20 & 22.5 & 20 & 18.8 & 20 & 18.0 & 21 & 19.3 & 20 & 20.8 & 20 \\
\hline \multirow[b]{2}{*}{ Hedonism } & $\begin{array}{l}\text { important to } \\
\text { have a good } \\
\text { time }\end{array}$ & 28.7 & 18 & 28.4 & 18 & 26.5 & 18 & 28.3 & 18 & 25.4 & 18 & 29.3 & 18 \\
\hline & $\begin{array}{l}\text { important to } \\
\text { seek fun and } \\
\text { things that } \\
\text { give pleasure }\end{array}$ & 27.5 & 19 & 26.5 & 19 & 25.9 & 19 & 24.5 & 19 & 23.0 & 19 & 25.2 & 19 \\
\hline \multirow{2}{*}{$\begin{array}{l}\text { Achieve- } \\
\text { ment }\end{array}$} & $\begin{array}{l}\text { important to } \\
\text { show abili- } \\
\text { ties and be } \\
\text { admired }\end{array}$ & 37.4 & 17 & 42.7 & 17 & 38.3 & 17 & 38.7 & 17 & 42.7 & 17 & 45.4 & 17 \\
\hline & $\begin{array}{l}\text { important to } \\
\text { be successful } \\
\text { and that peo- } \\
\text { ple recognize } \\
\text { achievements }\end{array}$ & 40.8 & 16 & 43.2 & 16 & 40.7 & 16 & 40.7 & 16 & 44.0 & 16 & 47.4 & 15 \\
\hline \multirow[t]{2}{*}{ Power } & $\begin{array}{l}\text { important to } \\
\text { be rich, have } \\
\text { money and } \\
\text { expensive } \\
\text { things }\end{array}$ & 20.2 & 21 & 17.5 & 21 & 15.5 & 21 & 18.8 & 20 & 19.3 & 21 & 18.6 & 21 \\
\hline & $\begin{array}{l}\text { important to } \\
\text { get respect } \\
\text { from others }\end{array}$ & 42.9 & 15 & 50.2 & 13 & 50.0 & 13 & 46.9 & 14 & 50.1 & 12 & 52.6 & 13 \\
\hline \multirow{2}{*}{ Security } & $\begin{array}{l}\text { important to } \\
\text { live in secure } \\
\text { and safe sur- } \\
\text { roundings }\end{array}$ & 80.6 & 2 & 79.6 & 3 & 78.3 & 3 & 73.6 & 3 & 76.2 & 3 & 80.6 & 4 \\
\hline & $\begin{array}{l}\text { important that } \\
\text { government } \\
\text { is strong and } \\
\text { ensures safety }\end{array}$ & 80.4 & 3 & 77.3 & 5 & 73.7 & 6 & 70.1 & 5 & 75.9 & 4 & 79.7 & 5 \\
\hline
\end{tabular}

Source: own work based on survey data (http://www.europeansocialsurvey.org, access date: 15.07.2014). 
By comparing the ranking based on the results of the last and the first survey, we can notice the changes in its composition (see Table 2). The importance of the following aspects has increased:

- loyalty towards friends (up from the 4th place to the 2 nd place),

- belief of a duty of caring for nature (up from the 5 th place to the 3 rd place),

- making one's own decisions in matters regarding oneself (up from the 6th place to the 7 th place),

- helping other people (up from the 10th place to the 8th place),

- hearing out people with different views and convictions (up from the 11th place to the 10th place),

- the desire to get respect from others (up from the 15 th place to the 13 th place)

- achieving meaningful success (up from the 16th place to the 15th place).

A decrease in importance can be noticed in the following cases:

- living in safe surroundings (down from the 2 nd to the 4 th place),

- expectation to be protected by the state from all kinds of danger (down from the 3rd to the 5 th place),

- need of abiding by rules and regulations (down from the 8 th to the 11 th place),

- following religious and family customs (down from the 6th to the 7 th place),

- willingness to seek out new activities (down from the 13 th to the 17 th place).

There is also a group of stances the position of which has not changed in comparison to the first survey. They include among others:

- creative approach and coming up with new ideas (in the 14th place),

- desire to be rich (in the 21 th place),

- conviction that people around the world should be treated equally (in the 1st place),

- being modest and humble (in the 12th place ),

- displaying one's abilities (in the 17th place).

More general conclusions on the changes in Poles' hierarchy of values can be formulated based on indicators determined for each of the domains of values ${ }^{7}$ (Table 3 ).

\footnotetext{
7 Each of the calculated indicator scores is the difference between the average for aspects comprising a given value and the average for all the answers. Before the scores were calculated the coding of the answers had been changed. Now 1 is the lowest score and 6 is the highest.
} 
Table 3. Indicator scores for individual human values

\begin{tabular}{|l|c|c|c|c|c|c|}
\cline { 2 - 7 } \multicolumn{1}{c|}{} & \multicolumn{7}{c|}{ ESS round } \\
\cline { 2 - 7 } \multicolumn{1}{c|}{} & 2002 & 2004 & 2006 & 2008 & 2010 & 2012 \\
\cline { 2 - 7 } \multicolumn{1}{c|}{} & \multicolumn{7}{c|}{ average indicator score } \\
\hline Security & 0.66 & 0.59 & 0.51 & 0.46 & 0.56 & 0.63 \\
\hline Conformity & 0.32 & 0.24 & 0.26 & 0.20 & 0.2 & 0.25 \\
\hline Tradition & 0.21 & 0.19 & 0.17 & 0.15 & 0.13 & 0.23 \\
\hline Benevolence & 0.43 & 0.49 & 0.41 & 0.47 & 0.52 & 0.55 \\
\hline Universalism & 0.45 & 0.42 & 0.49 & 0.48 & 0.48 & 0.57 \\
\hline Self -Direction & 0.12 & 0.12 & 0.09 & 0.15 & 0.15 & 0.18 \\
\hline Stimulation & -0.79 & -0.82 & -0.77 & -0.77 & -0.81 & -0.79 \\
\hline Hedonism & -0.97 & -0.99 & -0.94 & -0.93 & -1.07 & -1.00 \\
\hline Achievement & -0.44 & -0.36 & -0.37 & -0.37 & -0.32 & -0.27 \\
\hline Power & -0.80 & -0.73 & -0.71 & -0.66 & -0.61 & -0.66 \\
\hline
\end{tabular}

Source: own work based on survey data (http://www.europeansocialsurvey.org, access date: 15.07.2014).

High indicator stores are maintained with regard to security (between 0.51 and 0.66), benevolence (0.41-0.55) and universalism (0.42-0.57). In contrast, the following values have a negative indicator score: stimulation (between -0.81 and -0.77 ), hedonism (between -1.07 and -0.93 ) and power (between -0.8 and -0.61 ). The calculated indicator scores show that the importance of some groups of values is not subject to change and remains on a similar level in consecutive rounds. This applies to: hedonism, stimulation, security and tradition. On the other hand an increase in indicator scores is noticeable in the case of: self-direction (an increase by $50 \%$ ), achievement (by 62\%), benevolence (by 28\%), universalism (by $27 \%$ ) and power (by $21 \%)$.

Ordering values according to the "interest principle" demonstrates that within Poles' system of values a much greater importance is ascribed to values belonging to the categories of common and group values. Values comprising the group of individual interest have a lesser importance. By ordering the values according to the principle of "compatibility and conflict" we can come to the conclusions that the Poles' set of values is rather directed towards conservation than openness to change. At the same time self-transcendence prevails over self-enhancement.

\section{Differences in Poles' hierarchy of values}

The next part of the analysis consisted of examining whether there are differences in declared values based on age, sex, level of education and household income level. The differences pertain to both the place in the hierarchy of values, as well as the determined indicator score. Detailed data is presented in Table 4. 
Table 4. Poles' hierarchy of values based on the indicator score with differentiating variables included

\begin{tabular}{|c|c|c|c|c|c|c|c|c|c|c|c|c|c|c|c|c|c|c|c|c|}
\hline & \multicolumn{2}{|c|}{ Security } & \multicolumn{2}{|c|}{$\begin{array}{c}\text { Conform- } \\
\text { ity }\end{array}$} & \multicolumn{2}{|c|}{ Tradition } & \multicolumn{2}{|c|}{$\begin{array}{c}\text { Benevo- } \\
\text { lence }\end{array}$} & \multicolumn{2}{|c|}{$\begin{array}{l}\text { Universal- } \\
\text { ism }\end{array}$} & \multicolumn{2}{|c|}{$\begin{array}{c}\text { Self- } \\
\text { direction }\end{array}$} & \multicolumn{2}{|c|}{$\begin{array}{l}\text { Stimula- } \\
\text { tion }\end{array}$} & \multicolumn{2}{|c|}{ Hedonism } & \multicolumn{2}{|c|}{$\begin{array}{l}\text { Achieve- } \\
\text { ment }\end{array}$} & \multicolumn{2}{|c|}{ Power } \\
\hline \multicolumn{21}{|c|}{ Level of education } \\
\hline $\begin{array}{l}\text { Elementary } \\
\text { school or } \\
\text { lower }\end{array}$ & 0.89 & 2 & 0.8 & 4 & 0.9 & 1 & 0.39 & 5 & 0.82 & 3 & -0.49 & 7 & -1.39 & 10 & -1.37 & 9 & -0.7 & 8 & -0.49 & 6 \\
\hline $\begin{array}{l}\text { Middle } \\
\text { school }\end{array}$ & 0.31 & 2 & -0.29 & 8 & -0.4 & 9 & 0.48 & 1 & 0.23 & 3 & 0.23 & 3 & -0.18 & 6 & -0.25 & 7 & 0.11 & 5 & -0.40 & 9 \\
\hline $\begin{array}{l}\text { Vocational } \\
\text { school }\end{array}$ & 0.59 & 1 & 0.28 & 5 & 0.28 & 4 & 0.34 & 3 & 0.47 & 2 & 0.22 & 6 & -0.70 & 9 & -0.81 & 10 & -0.28 & 7 & -0.63 & 8 \\
\hline $\begin{array}{l}\text { Secondary } \\
\text { school }\end{array}$ & 0.66 & 1 & 0.23 & 5 & 0.16 & 6 & 0.56 & 3 & 0.58 & 2 & 0.23 & 4 & -0.75 & 9 & -1.07 & 10 & -0.25 & 7 & -0.69 & 8 \\
\hline $\begin{array}{l}\text { Higher } \\
\text { education }\end{array}$ & 0.52 & 3 & 0.21 & 5 & 0.04 & 6 & 0.61 & 2 & 0.62 & 1 & 0.40 & 4 & -0.85 & 9 & -1.09 & 10 & -0.12 & 7 & -0.65 & 8 \\
\hline \multicolumn{21}{|c|}{ Net household income } \\
\hline $\begin{array}{l}\text { 1st decile } \\
\text { group }\end{array}$ & 0,71 & 1 & 0.55 & 5 & 0.66 & 3 & 0.57 & 4 & 0.71 & 1 & -0.08 & 6 & -1.12 & 9 & -1.20 & 10 & -0.45 & 7 & -0.70 & 8 \\
\hline $\begin{array}{l}\text { 2nd decile } \\
\text { group }\end{array}$ & 0,74 & 1 & 0.39 & 5 & 0.50 & 4 & 0.55 & 3 & 0.64 & 2 & 0.01 & 6 & -0.87 & 9 & -1.18 & 10 & -0.39 & 7 & -0.78 & 8 \\
\hline $\begin{array}{l}\text { 3rd decile } \\
\text { group }\end{array}$ & 0,68 & 1 & 0.33 & 5 & 0.39 & 4 & 0.62 & 3 & 0.65 & 2 & 0.13 & 6 & -0.98 & 9 & -1.18 & 10 & -0.32 & 7 & -0.69 & 8 \\
\hline $\begin{array}{l}\text { 4th decile } \\
\text { group }\end{array}$ & 0,67 & 1 & 0.32 & 5 & 0.34 & 4 & 0.58 & 3 & 0.60 & 2 & 0.25 & 6 & -0.81 & 8 & -1.04 & 10 & -0.40 & 7 & -0.82 & 9 \\
\hline $\begin{array}{l}\text { 5th decile } \\
\text { group }\end{array}$ & 0,62 & 1 & 0.34 & 4 & 0.23 & 5 & 0.52 & 2 & 0.49 & 3 & 0.08 & 6 & -0.71 & 9 & -0.90 & 10 & -0.32 & 7 & -0.60 & 8 \\
\hline $\begin{array}{l}\text { 6th decile } \\
\text { group }\end{array}$ & 0,65 & 1 & 0.20 & 6 & 0.23 & 5 & 0.56 & 3 & 0.58 & 2 & 0.26 & 4 & -0.77 & 9 & -0.96 & 10 & -0.36 & 7 & -0.70 & 8 \\
\hline $\begin{array}{l}\text { 7th decile } \\
\text { group }\end{array}$ & 0,66 & 1 & 0.24 & 4 & 0.20 & 6 & 0.57 & 3 & 0.60 & 2 & 0.24 & 4 & -0.93 & 9 & -1.01 & 10 & -0.26 & 7 & -0.61 & 8 \\
\hline $\begin{array}{l}\text { 8th decile } \\
\text { group }\end{array}$ & 0,59 & 1 & 0.18 & 5 & 0.07 & 6 & 0.56 & 2 & 0.55 & 3 & 0.30 & 4 & -0.70 & 8 & -0.88 & 10 & -0.16 & 7 & -0.78 & 9 \\
\hline $\begin{array}{l}\text { 9th decile } \\
\text { group }\end{array}$ & 0,55 & 3 & 0.09 & 5 & -0.01 & 6 & 0.57 & 1 & 0.57 & 1 & 0.25 & 4 & -0.56 & 8 & -0.87 & 10 & -0.17 & 7 & -0.72 & 9 \\
\hline $\begin{array}{l}\text { 10th decile } \\
\text { group }\end{array}$ & 0,31 & 4 & 0.06 & 5 & -0.01 & 6 & 0.52 & 2 & 0.56 & 1 & 0.50 & 3 & -0.57 & 8 & -0.88 & 10 & -0.15 & 7 & -0.62 & 9 \\
\hline \multicolumn{21}{|c|}{ Age } \\
\hline $15-19$ & 0.27 & 2 & -0.32 & 9 & -0.28 & 8 & 0.44 & 1 & 0.23 & 3 & 0.22 & 4 & -0.19 & 6 & -0.27 & 7 & 0.17 & 5 & -0.41 & 10 \\
\hline $20-29$ & 0.41 & 3 & -0.11 & 6 & -0.22 & 7 & 0.51 & 1 & 0.44 & 2 & 0.28 & 4 & -0.47 & 8 & -0.59 & 10 & $\mathbf{0 , 0 0}$ & 5 & -0.49 & 9 \\
\hline $30-44$ & 0.52 & 2 & 0.13 & 5 & 0.07 & 6 & 0.53 & 1 & 0.52 & 2 & 0.25 & 4 & -0.63 & 8 & -0.95 & 10 & -0.10 & 7 & -0.63 & 8 \\
\hline $45-59$ & 0.72 & 1 & 0.40 & 5 & 0.41 & 4 & 0.59 & 3 & 0.63 & 2 & 0.20 & 6 & -0.93 & 9 & -1.17 & 10 & -0.43 & 7 & -0.74 & 8 \\
\hline $\begin{array}{l}60 \text { and } \\
\text { above }\end{array}$ & 0.89 & 1 & 0.65 & 4 & 0.68 & 3 & 0.59 & 5 & 0.74 & 2 & $\mathbf{0 , 0 0}$ & 6 & -1.21 & 9 & -1.39 & 10 & -0.59 & 7 & -0.78 & 8 \\
\hline \multicolumn{21}{|c|}{ Sex } \\
\hline Male & 0.50 & 1 & 0.15 & 5 & 0.12 & 6 & 0.45 & 3 & 0.48 & 2 & 0.26 & 4 & -0.68 & 9 & -0.76 & 10 & -0.23 & 7 & -0.53 & 8 \\
\hline Female & 0.75 & 1 & 0.35 & 4 & 0.33 & 5 & 0.65 & 3 & 0.66 & 2 & 0.11 & 6 & -0.90 & 9 & -1.24 & 10 & -0.31 & 7 & -0.77 & 8 \\
\hline
\end{tabular}

Source: own work based on survey data (http://www.europeansocialsurvey.org, access date: 15.07.2014). 
Statistical analysis of indicator scores proves that the hierarchy of values of male and female respondents is the same. Differences between individual values are not statistically relevant. However a difference can be noticed with regard to the place of individual values in the hierarchy. This applies to conformity, tradition and self-direction. Differences in declared values are also based on the level of education. The result of variance analysis shows that the hypothesis that average indicator scores remain the same in view of the same level of education should be dismissed. Respondents with elementary school education value tradition (0.90) and security (0.89). Indicators for these values decrease along with the increasing level of education. ${ }^{8}$ For subjects with higher education the indicator scores are 0.04 and 0.52 respectively. An opposite situation has been identified in the case of self-direction $(-0.49)$, stimulation $(-1.39)$ and achievement (-0.70). Low indicator scores increase along with the changing level of education.

A similar pattern is noticeable, if net household income is taken into account. ${ }^{9}$ Participants with a low income level ascribe greater significance to security, conformity and tradition than subjects with the highest income level. It is worth noting that regardless of income level similar indicator scores apply to benevolence and there is also little difference in the case of valuing universalism. However, it does not translate to identical places in the hierarchy. Both values occupy different but close places in the hierarchy in individual income groups.

In the case of the remaining values i.e. self-direction and achievement it is not possible to identify a clear tendency, since in spite of low scores for the lowest income groups and higher scores for the highest income groups the scores for the middle decile groups are diverse. This indicates that the significance of these values for those groups is diversified.

The last variable included in the analysis was the age of the respondents. The result of variance analysis proves that the hypothesis that average indicator scores remain the same regardless of age should be dismissed. Calculated scores indicate that the youngest subjects (i.e. aged between 15 and 19) place lower value on security comparing to other age groups. A similar situation is present it the case of universalism. This age group is also characterized by an opposition to conformity and breaking with tradition. Both values occupy last places in the hierarchy of values of the youngest respondents while in the following age groups they gain an increasingly greater meaning. A reverse situation is noticeable in the case of self-direction,

\footnotetext{
8 Subjects with middle school education are an exception from the observed relation. This group consists predominantly ( $90 \%$ ) of people aged between 15 and 19. In that case including middle school education in the analysis would be equivalent to conducting an analysis based on age.

9 Statistically relevant differences between average indicator scores for individual decile groups were identified in the case of all the values except for benevolence and power.
} 
hedonism and achievement. Youngest participants ascribe greater importance to these values comparing to older respondents comprising other age groups.

\section{Conclusions}

The results of ESS indicate that the hierarchy of values cherished by Poles remains relatively stable. The most significant values are security, universalism and benevolence. The least important values are hedonism, stimulation and power. The significance of the following values has not been subject to change: hedonism, stimulation, security and tradition. On the other hand we can observe an increase in importance in case of the following values: self-direction, achievement, benevolence, universalism and power.

There are no identifiable differences in the hierarchies of values of women and men. However there are noticeable differences depending on the level of education, household income level and age of surveyed respondents. The increase in the level of education translates into a decline in the value of indicators related to tradition and security, and increase in the value of self-determination, stimulation and needs of accomplishments. Great importance to tradition and security is also attached by the people on the lowest income, while the importance of these values decreases among those with the highest income.

The youngest respondents attach less importance to security issues, they have less understanding of the issues of universalism and tradition. Among them there is also lack of consent for conformity. This situation is changing in the successive age groups where you can observe the increase in the value of respective indicators.

\section{References}

Brzozowski, P. (2007). Wzorcowa hierarchia wartości: polska, europejska czy uniwersalna? Psychologiczne badania empiryczne. Lublin: Wydawnictwo Uniwersytetu Marii CurieSkłodowskiej.

Dyczewski, L. (2001). Miejsce i funkcja wartości w kulturze. In: L. Dyczewski (ed.), Kultura w kręgu wartości. Lublin: Towarzystwo Naukowe KUL.

Jasińska-Kania A. (ed.) (2012). Wartości i zmiany: przemiany postaw Polaków w jednoczacej się Europie. Warszawa: Scholar.

Lachowski, S. (2012). Droga ważniejsza niż cel, Wartości w życiu i biznesie. Warszawa: Studio EMKA. 
Nowak, S. (2007). System wartości społeczeństwa polskiego. In: I. Krzemiński, J. Raciboski (eds.), Oswajanie Wielkiej Zmiany. Instytut Socjologii UW o polskiej transformacji. Warszawa: IFiS PAN.

Schwartz, S.H. (1992). Universals in the content and structure of values: Theory and empirical tests in 20 countries. In: M. Zanna (ed.), Advances in experimental social psychology. New York: Academic Press.

Schwartz, S.H. (2005). Basic human values: Their content and structure across countries. In: A. Tamayo, J.B. Porto (eds.), Valores e comportamento nas organizações. Petrópolis: Vozes.

Schwartz, S.H. (2003). A proposal for measuring value orientations across nations. Questionnaire Package of the European Social Survey (pp. 259-290). Downloaded: http://www. europeansocialsurvey.org (access date: 15.07. 2014).

Szymczyk, J. (2010). Wokół wartości i więzi społecznych Polaków. Wybrane aspekty i tendencje. Zeszyty Naukowe KUL, 4 (212).

Wartości i normy. Komunikat z badań, BS/111/2013, CBOS. Downloaded: http://www.cbos.pl/ SPISKOM.POL/2013/K_111_13.PDF (access date: 20.07. 2014).

Ziółkowski, M. (2006). Zmiany systemu wartości. In: J. Wasilewski (ed.), Współczesne społeczeństwo polskie. Dynamika zmian. Warszawa: Scholar. 